\title{
Protein-Hydrocarbon Interactions
}

\author{
INTERACTIONS OF VARIOUS PROTEINS WITH PURE DECANE
}

\author{
By R. CECIL AND C. F. LOUIS \\ Department of Biochemistry, University of Oxford, Oxford OX1 3QU, U.K.
}

(Received 21 November 1969)

\begin{abstract}
1. Solutions of a number of proteins were subjected to gentle agitation in the presence of small quantities of decane. 2. Some of the protein was lost from solution and adsorbed on the surface of the emulsion formed; at the same time some of the decane was bound to the protein remaining in solution. 3. The two processes were found to be related and a mechanism is proposed to explain the relationship. 4. With lysozyme and ribonuclease, the protein in the aqueous phase of an emulsion exhibited normal enzymic activity, whereas the fraction adsorbed on the interface was much less active but recovered activity on desorption.
\end{abstract}

When aqueous solutions of a protein and hydrocarbon are mixed together an emulsion of hydrocarbon in water is obtained: protein can leave the aqueous phase and form a layer at the interface, and hydrocarbon can enter the aqueous phase to combine with protein in solution. A considerable amount of work has already been reported with this type of system, but in most cases the hydrocarbon contained a polar compound such as a long-chain fatty acid or detergent (Fraser, Kaplan \& Schulman, 1955; Fraser \& Schulman, 1956; Elkes, Frazer, Schulman \& Stewart, 1945; Ghosh \& Bull, 1963). In these experiments only the amount of protein adsorbed by a given amount of hydrocarbon emulsion was measured. Ghosh \& Bull (1963) and Cockbain (1956) studied the adsorption of bovine serum albumin on hydrocarbon in water emulsions; the former work was mostly confined to surfacetension experiments, the latter with the effect of changing conditions on the amount of protein adsorbed per unit area of interface.

The binding of hydrocarbons by protein in aqueous solution has been investigated in some detail by Wishnia (1962) and Wishnia \& Pinder (1964), who studied the solubility of small hydrocarbon molecules in solutions of bovine serum albumin, haemoglobin and lysozyme. Mohammadzadeh-K., Feeney, Samuels \& Smith (1967) studied the binding of various liquid hydrocarbons to bovine serum albumin, lactoglobulin, chicken ovomucoid and chicken ovalbumin. Ray, Reynolds, Polet \& Steinhardt (1966) and Reynolds, Herbert \& Steinhardt (1967) studied the binding of various long-chain hydrocarbons to bovine serum albumin.

In this work, both constant and different volumes of decane were added to different initial concentrations of various extracellular proteins. Both the amount of protein adsorbed at the decane/water interface and the amount of decane bound by protein in solution were measured. The enzymic activity of lysozyme and ribonuclease in the presence of decane was also studied.

\section{MATERIALS}

n-Decane. $n$-Decane was obtained from British Drug Houses Ltd., Poole, Dorset, U.K. It was washed three times with $4 \mathrm{M}-\mathrm{NaOH}$ and then washed repeatedly with water until the washings were no longer alkaline. It was then washed repeatedly with conc. $\mathrm{H}_{2} \mathrm{SO}_{4}$ until the acid was no longer yellow after mixing. It was then distilled and the fraction boiling at $171-172^{\circ} \mathrm{C}$ collected. A sample was injected on to a $1 \frac{1}{2} \%$ silicone gum-rubber g.l.c. column at $100^{\circ} \mathrm{C}$; only one peak was observed and by measuring the peak height it was concluded that the decane was at least $99.9 \%$ pure. It was stored in Pyrex bottles at $2^{\circ} \mathrm{C}$ in the dark.

n-Heptane. The purification of heptane, obtained from British Drug Houses Ltd., was the same as for decane. The fraction boiling at $98-99^{\circ} \mathrm{C}$ was collected and g.l.c. showed the hydrocarbon to be at least $99.9 \%$ pure. It was stored in Pyrex bottles at $2^{\circ} \mathrm{C}$ in the dark.

$\left[{ }^{3} \mathrm{H}\right] \mathrm{n}$-Decane. $\left[{ }^{3} \mathrm{H}\right] n$-Decane was obtained from The Radiochemical Centre, Amersham, Bucks., U.K. It was diluted with $n$-decane to give a specific radioactivity of approx. $5 \mathrm{mCi} / \mathrm{ml}$. The purification procedure described above was repeated, except for the final distillation, on the diluted $\left[{ }^{3} \mathrm{H}\right]$ decane to remove any $\left[{ }^{3} \mathrm{H}\right]$ alcohols present as impurities. It was stored in a desiccator at $2^{\circ} \mathrm{C}$ in the dark.

$\left[{ }^{14} \mathrm{C}\right] \mathrm{n}$-Decane. $\left[{ }^{14} \mathrm{C}\right] n$-Decane was obtained from The Radiochemical Centre. It was diluted with $n$-decane to give a specific radioactivity of $0.05 \mathrm{mCi} / \mathrm{ml}$. The washing 
procedure described for the ${ }^{3} \mathrm{H}$-labelled material was repeated. It was stored in a desiccator at $2^{\circ} \mathrm{C}$ in the dark.

Bovine serum albumin. Crystalline bovine serum albumin was obtained from Armour Pharmaceutical Co. Ltd., Eastbourne, Sussex, U.K. (batch MA 1670). Solutions were made up in pH 7.0 buffer (see below for com. position) and concentrations estimated from the extinction at $280 \mathrm{~nm}$. Foster \& Sterman (1956) give $E_{1 \mathrm{~cm}}^{1 \%} 6.67$. It was stored at $2^{\circ} \mathrm{C}$ in a desiccator.

Lysozyme. Lysozyme (twice crystallized, salt-free, from hen's-egg white; batch 7GA) was obtained from Worthington Biochemical Corp., Freehold, N.J., U.S.A. Solutions were made up in pH2.0 buffer (see below for composition) and concentrations estimated from the extinction of $280 \mathrm{~nm}$. Sophianopoulos, Rhodes, Holcomb \& van Holde (1962) give $E_{1}^{1 \%} 26.35$ at pH5.4, and it was found that $E_{1 \mathrm{~cm}}^{1 \%}$ at pH5.4 is identical with that at pH2.0 and $\mathrm{pH}$ 7.0. The protein was stored at $2^{\circ} \mathrm{C}$ in a desiccator.

Ribonuclease. Ribonuclease (five times crystallized from bovine pancreas; batch 115B-8720) was obtained from the Sigma (London) Chemical Co., London S.W.6, U.K. Solutions were made up in pH 7.0 buffer and concentrations estimated from the extinction at $278 \mathrm{~nm}$. Sela, Anfinsen \& Harrington (1957) give the molar extinction coefficient as $\epsilon \mathbf{9 8 0 0}$. It was stored at $2^{\circ} \mathrm{C}$ in a desiccator.

Insulin. Crystalline (zinc) ox insulin (batch 10931D) was obtained from Boots Pure Drug Co. Ltd., Nottingham, U.K. It was stored at $2^{\circ} \mathrm{C}$ in a vessel containing a saturated solution of $\mathrm{CaCl}_{2}$, which maintains a relative humidity of $40 \%$ (Handbook of Chemistry and Physics, 1951-52). The moisture content of insulin so stored is 9.9\% (Cecil \& Loening, 1960). Solutions were made up in $0.01 \mathrm{M}-\mathrm{HCl}$ and concentrations were estimated from the extinction at $277 \mathrm{~nm}$. The molar extinction coefficient is given by Cecil \& Weitzman (1964) as $\epsilon 6130$.

Carbonic anhydrase. Carbonic anhydrase (from bovine e1ythrocytes, salt-free, freeze-dried; batch 17512) was obtained fromKoch-Light Laboratories Ltd., Colnbrook, Bucks., U.K. Solutions were made up in pH7.0 buffer and concentrations estimated from the extinction at $280 \mathrm{~nm}$. Nyman \& Lindskog (1964) give $E_{1 \mathrm{~cm}}^{1 \%} 19.0$. It was stored at $2^{\circ} \mathrm{C}$ in a desiccator.

Glutamate dehydrogenase. Glutamate dehydrogenase $\left[\left(\mathrm{NH}_{4}\right)_{2} \mathrm{SO}_{4}\right.$ suspension; batch 6028450] was obtained from the Boehringer Corp. (London) Ltd., London W.5, U.K. Solutions were made up in pH 7.0 buffer and concentrations estimated from the extinction at $279 \mathrm{~nm}$. Olson \& Anfinsen (1952) give $E_{1 \% \mathrm{~m}}^{1 \%}$ 9.7.

Micrococcus lysodeikticus. Micrococcus lysodeikticus (dried cells) was obtained from the Sigma (London) Chemical Co. It was stored at $2^{\circ} \mathrm{C}$ in a desiccator.

Cytidine 2':3'-cyclic monophosphoric acid sodium salt. Cytidine 2': $3^{\prime}$-cyclic monophosphoric acid sodium salt was obtained from the Sigma (London) Chemical Co. It was stored at $2^{\circ} \mathrm{C}$ in a desiccator.

Buffer solutions. The buffer solutions were made up as follows: $\mathrm{pH} 2.0,10 \mathrm{~mm}-\mathrm{HCl}-100 \mathrm{~mm}-\mathrm{NaCl} ; \mathrm{pH} \mathrm{6.24,} 21 \mathrm{~mm}$ $\mathrm{Na}_{2} \mathrm{HPO}_{4}-79 \mathrm{~mm}-\mathrm{NaH}_{2} \mathrm{PO}_{4} ; \mathrm{pH} 7.0,61 \mathrm{~mm}-\mathrm{Na}_{2} \mathrm{HPO}_{4}-$ $39 \mathrm{mM}-\mathrm{NaH}_{2} \mathrm{PO}_{4}$.

Scintillator fluid. Scintillator fluid was made up as follows: $8 \mathrm{~g}$ of 5-(4-biphenyl)-2-(4-tert.-butylphenyl)-1oxa-3,4-diazole [obtained from Ciba (A.R.L.) Ltd.,
Duxford, Cambs., U.K.], $60 \mathrm{~g}$ of naphthalene, $100 \mathrm{ml}$ of methanol, and dioxan to $1000 \mathrm{ml}$.

Other reagents. All other reagents used were analytical grade.

\section{APPARATUS AND METHODS}

Determination of protein concentration. Where the protein might have undergone some conformational change affecting the absorption spectrum, concentrations were measured by the methods of Lowry, Rosebrough, Farr \& Randall (1951).

Formation and treatment of emulsions. In all experiments, unless otherwise stated, $6 \mathrm{ml}$ samples of aqueous protein solution were pipetted into $15 \mathrm{ml}$ stoppered test tubes. The required volume of hydrocarbon was then added to each tube. The tubes were fixed in clips screwed on to a hardboard disc that covered one side of a bicycle wheel (referred to below as 'the wheel'). A string belt was used to connect the outer rim of the wheel with a small electric motor so that it rotated approx. 30 times/ min. The tubes, unless otherwise stated, were left on the wheel for $24 \mathrm{~h}$ at $2^{\circ} \mathrm{C}$, during which time an opaque emulsion was formed.

After $24 \mathrm{~h}$ the tubes were removed. Originally the hydrocarbon phase was removed by spinning the contents of each tube in a plastic tube for $30 \mathrm{~min}$ at $10000 \mathrm{rev} . / \mathrm{min}$ in a small bench centrifuge. The plastic tube was held in a solid $\mathrm{CO}_{2}$-ethanol solution, which froze the contents of the tube, and the supernatant hydrocarbon phase was removed by sawing through the frozen test tube. The plastic test tube, minus top, was placed in a glass test tube and the aqueous phase was allowed to thaw and then assayed for enzymic activities. Later a better technique was evolved for removing the hydrocarbon. In this the solution was centrifuged in a Beckman Spinco model $\mathrm{L}$ preparative ultracentrifuge with an $\mathrm{SW} 39$ rotor at $38000 \mathrm{rev} . / \mathrm{min}$ at $2^{\circ} \mathrm{C}$ for $30 \mathrm{~min}$. The tubes were then removed from the rotor, a hole was pierced in the bottom of each and the first $4 \mathrm{ml}$ of the aqueous phase was retained for assay. Identical results were obtained with both methods, but the latter was simpler and it also enabled supernatant hydrocarbon phase to be assayed if required.

Formation of emulsions by ultrasonic vibration. Hydrocarbon emulsions were also formed by ultrasonic vibration by using an MSE $100 \mathrm{~W}$ ultrasonic disintegrator. The probe was placed just below the surface of the liquid and switched on for $15 \mathrm{~s}$.

Measurement of particle size. Measurement of particle size distributions of different emulsions was attempted by using a Coulter model A (Medical) counter. A $30 \mu \mathrm{m}$ aperture-diameter orifice was used with the counter.

Lysozyme activity. The method of assay of lysozyme is that described by Shugar (1952) in which the rate of lysis of Micrococcus lysodeikticus cells is followed by observing the fall in turbidity by using a spectrophotometer set at $450 \mathrm{~nm}$.

Ribonuclease activity. Ribonuclease was assayed by the method described by Crook, Mathias \& Rabin (1960). This is a spectrophotometric assay based on the change in extinction at $284 \mathrm{~nm}$ resulting from the hydrolysis of cytidine $2^{\prime}: 3^{\prime}$-cyclic phosphate by ribonuclease to cytidine $3^{\prime}$-phosphate.

Measurement of bound decane. The proteins concerned 
were equilibrated with ${ }^{14} \mathrm{C}$ - or ${ }^{3} \mathrm{H}$-labelled samples of decane and the aqueous phase separated as described. A $0.5 \mathrm{ml}$ portion of aqueous phase was added to $4.5 \mathrm{ml}$ of scintillation fluid and the radioactivity measured in an IAL scintillation counter. Background counts, with buffer only, varied between 0.25 and 0.5 c.p.s. (counts/ second); in the presence of protein values of about 10 c.p.s. were obtained.

\section{RESULTS}

\section{Adsorption of protein on hydrocarbon-in-water emulsions}

Emulsions were formed as described above from $6 \mathrm{ml}$ samples of protein solution together with the required volume of decane. The amount of protein adsorbed at the interface was determined by measuring the drop in concentration in the aqueous phase.

Fig. 1 shows the result of an experiment in which $6 \mathrm{ml}$ samples of $20 \mu \mathrm{M}$-lysozyme at $\mathrm{pH} 2.0$ were equilibrated with various volumes of decane. The concentration of protein remaining in solution after centrifugation was plotted against the volume of decane added, showing that a maximum of $50 \%$ of the protein was adsorbed on the decane. This experiment was repeated with initial concentrations of $48 \mu \mathrm{M}$ - and $101 \mu \mathrm{M}$-lysozyme and the maximum loss of protein from solution remained at $50 \%$.

It was not possible to measure the amount of the hydrocarbon that was emulsified, although it is likely that all the available hydrocarbon was emulsified when small volumes were added and less than the maximum amount of protein was lost from solution. When larger volumes were added, which did not cause any further loss of protein from solution, it is likely that there was some free hydrocarbon present that had no protein bound to it. Centrifugation removed all the hydrocarbon, whether emulsified or free, and the term 'hydrocarbon phase' refers to all the liquid hydrocarbon

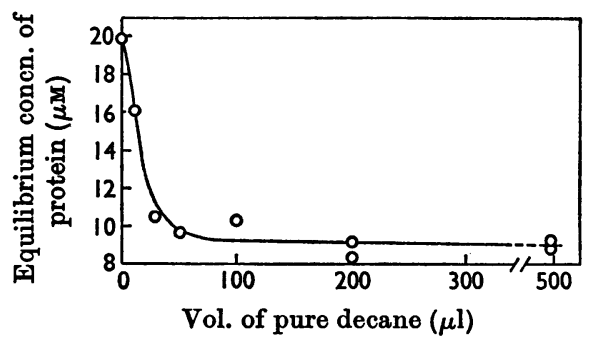

Fig. 1. Equilibrium concentration of lysozyme remaining in solution at $\mathrm{pH} 2.0$ plotted against the volume of decane added. Samples $(6 \mathrm{ml})$ of $20 \mu \mathrm{M}$-lysozyme were equilibrated with different volumes of decane and the equilibrium concentration of protein was measured as described in the text. with its quota of bound protein. The term 'aqueous phase' refers to the solution after removal of the hydrocarbon phase together with any protein, and any hydrocarbon bound to the protein, that it may contain.

Similar results were obtained with the other proteins. Insulin gave a maximum loss from solution of $50 \%$ at $\mathrm{pH} 2.0$, serum albumin gave $65 \%$ at $\mathrm{pH} 7.0$ and ribonuclease gave $50 \%$ at $\mathrm{pH7.0}$. Substitution of $n$-heptane for decane did not affect the amount of protein lost from solution.

Intracellular proteins. With both glutamate dehydrogenase and carbonic anhydrase there was an immediate flocculation of protein from solution as soon as decane was added. After removal of the hydrocarbon phase and flocculent precipitate by centrifugation, less than $5 \%$ of the protein remained in solution even when a very small volume of decane had been added.

Measurement of particle size. Attempts were made to measure the particle size distribution of the emulsion by using a Coulter counter. These were unsuccessful since no plateau in the count could be obtained as the voltage was raised (Blades \& Flavell, 1963). This means that the distribution of particle size is too large for the counter to be able to resolve the individual particles.

This large distribution of particle size was confirmed by photomicrography of the emulsions, by using Dowex polyvinyl beads of $2.0 \mu \mathrm{m}$ diameter for comparison. The largest particles were about $2 \mu \mathrm{m}$, the smallest less than $0.1 \mu \mathrm{m}$ in diameter.

Formation of emulsions by ultrasonic vibration. It was found that, if the contents of a series of tubes containing the same concentration of lysozyme with different volumes of decane were subjected to ultrasonic vibration for $15 \mathrm{~s}$ and then equilibrated on the wheel for $24 \mathrm{~h}$, the loss of protein from solution was identical with that obtained when there was no prior ultrasonic vibration of the solutions. If agitation on the wheel was omitted there was only a small fall in concentration irrespective of whether the tubes were spun immedi-

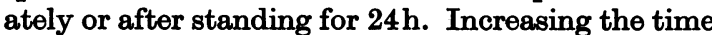
of the ultrasonic vibration from $15 \mathrm{~s}$ to $30 \mathrm{~s}$ made no significant difference to these results.

It would therefore appear that the rate of formation of an emulsion stabilized by proteins is limited by the rate of adsorption of protein at the interface rather than by the rate of dispersion of the hydrocarbon phase.

\section{Recovery of adsorbed protein from the hydrocarbon phase of emulsions}

It was found that proteins could be recovered in good yield after adsorption on the hydrocarbon/ water interface. The hydrocarbon phase of the 
Table 1. Recovery of proteins adsorbed on the hydrocarbon phase of the emulsions

Emulsions were formed as described in the text and the aqueous and hydrocarbon phases were separated by centrifugation. The hydrocarbon phase was suspended in $6 \mathrm{ml}$ of the original buffer together with $0.5 \mathrm{ml}$ of decanol and re-equilibrated on the wheel for $24 \mathrm{~h}$. The two phases were again separated by centrifugation and the concentration of protein in the aqueous phase was determined by Lowry et al. (1951).

\begin{tabular}{|c|c|c|c|c|}
\hline Protein ... & $\begin{array}{l}\text { Insulin } \\
\text { pH } 2.0\end{array}$ & $\begin{array}{l}\text { Lysozyme } \\
\text { pH } 2.0\end{array}$ & $\begin{array}{c}\text { Bovine serum } \\
\text { albumin } \\
\text { pH } 7.0\end{array}$ & $\begin{array}{c}\text { Ribonuclease } \\
\text { pH } 7.0\end{array}$ \\
\hline $10^{5} \times$ Initial molarity & 11.76 & 2.31 & 1.30 & 2.30 \\
\hline $\begin{array}{l}10^{5} \times \text { Molarity in aqueous phase after } \\
\text { equilibration with decane }\end{array}$ & 4.42 & 1.18 & 0.47 & 0.80 \\
\hline $\begin{array}{l}10^{5} \times \text { Molarity in new aqueous phase after } \\
\text { re-equilibration }\end{array}$ & 6.54 & 0.83 & 0.32 & 0.75 \\
\hline Percentage recovery of protein from & 89 & 73 & 39 & 50 \\
\hline
\end{tabular}

einulsion was separated in the usual way and reequilibrated on the wheel for $24 \mathrm{~h}$ with $6 \mathrm{ml}$ of the original buffer together with $0.5 \mathrm{ml}$ of $n$-decanol. (The effect of alcohols on these emulsions is discussed in detail by Cecil \& Louis, 1970.) Table 1 shows the results obtained. Protein could be recovered by re-equilibration with buffer alone, but better yields were obtained in the presence of alcohols. This technique was used for the experiments described below on the activities of lysozyme and ribonuclease on emulsions.

\section{Binding of decane by protein in aqueous solution}

In addition to proteins being adsorbed on the surface of an emulsion particle it was found that decane is bound by protein solutions in equilibrium with an emulsion. Experiments were carried out to investigate the binding of decane to various proteins. The radioactivity of the solutions can be taken as being directly proportional to the amount of decane bound, since the solubility of decane in water is approx. $1.0 \mathrm{~nm}$.

It was found that at $22 \pm 1^{\circ} \mathrm{C}$ decane was bound by bovine serum albumin, lysozyme and insulin, but not by ribonuclease. When given amounts of decane and protein solution were equilibrated for various times equilibrium was reached within $5 \mathrm{~h}$.

The results shown in Figs. 2-4 were obtained when $10 \mu \mathrm{l}$ of decane was added to $6 \mathrm{ml}$ of different concentrations of protein. It was found that, with the three proteins that did bind decane at $22^{\circ} \mathrm{C}$, the number of $\mathrm{mol}$ of decane bound $/ \mathrm{mol}$ of protein $(\bar{v})$ increased with decreasing concentration of protein.

An experiment was carried out in which $6 \mathrm{ml}$ samples of $10.4 \mu \mathrm{M}$-lysozyme at $\mathrm{pH} 2.0$ were equilibrated with different volumes of radioactive decane and both $\bar{\nu}$ and the amount of protein remaining in solution measured. The results (Fig.

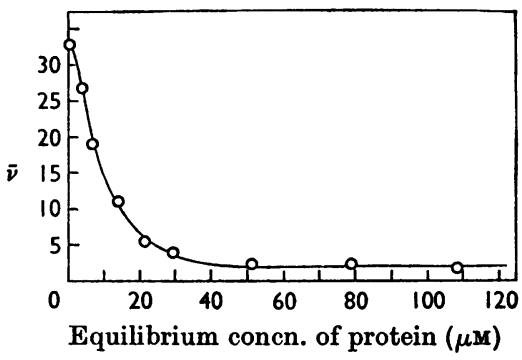

Fig. 2. Number of $\mathrm{mol}$ of decane bound/mol of bovine serum albumin $(\bar{v})$ at $\mathrm{pH}$ 7.0. Samples $(6 \mathrm{ml})$ of different concentrations of bovine serum albumin were equilibrated with $10 \mu \mathrm{l}$ of radioactive decane as described in the text.

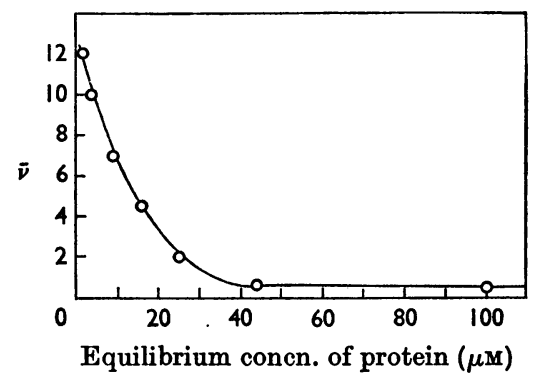

Fig. 3. Number of mol of decane bound/mol of lysozyme (i) at pH 2.0. Samples $(6 \mathrm{ml})$ of different concentrations of lysozyme were equilibrated with $10 \mu$ l of radioactive decane as described in the text.

5) show that $\bar{\nu}$ rises to a maximum of 12 . When this experiment was repeated with an initial concentration of $29 \mu \mathrm{M}$-lysozyme the maximum value of $\bar{\nu}$ was only 3 .

The extent of binding of decane was also 


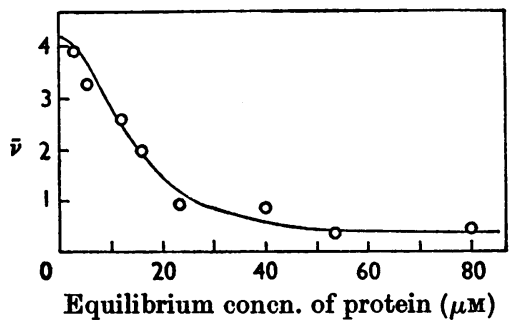

Fig. 4. Number of $\mathrm{mol}$ of decane bound/ $\mathrm{mol}$ of insulin (i) at $\mathrm{pH}$ 2.0. Samples $(6 \mathrm{ml})$ of different concentrations of insulin were equilibrated with $10 \mu$ l of radioactive decane as described in the text.

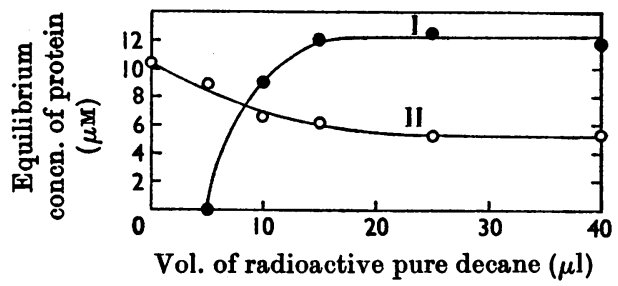

Fig. 5. Number of mol of decane bound/mol of lysozyme (i) at $\mathrm{pH} 2.0$ and the equilibrium concentration of protein remaining in solution plotted against the volume of decane added. Samples $(6 \mathrm{ml})$ of $10.4 \mu \mathrm{M}$-lysozyme were equilibrated with different volumes of radioactive decane and both $\bar{\nu}$ and the equilibrium protein concentration were measured as described in the text. Curve I, $\bar{\nu}$; curve II, equilibrium concentration of protein.

measured at $2^{\circ} \mathrm{C}$, but the results were not reproducible. In most of the experiments serum albumin bound approximately the same amount of decane as at $22^{\circ} \mathrm{C}$, whereas insulin, lysozyme and ribonuclease bound none. In some experiments, however, insulin and lysozyme exhibited some binding. Unfortunately no reason could be found for this inconsistency.

\section{Loss of decane bound to proteins in solution}

The binding of decane by protein was shown to be reversible. In a typical experiment $6 \mathrm{ml}$ of $10 \mu \mathrm{M}$-lysozyme at $\mathrm{pH} 2.0$ was equilibrated with $20 \mu l$ of radioactive decane. After removal of the hydrocarbon phase the value of $\bar{\nu}$ was 6 . This solution was left on the wheel for a further $24 \mathrm{~h}$ and then centrifuged to remove any free decane that had formed. The value of $\bar{\nu}$ was then found to be zero.

\section{Effect of emulsions on the activity of enzymes}

Lysozyme. Micrococcus lysodeikticus suspensions, approx. $0.1 \mathrm{mg} / \mathrm{ml}$ in pH6.24 buffer, were used as the substrate for comparing the activities of different lysozyme solutions. The initial slope of the turbidity change-time curve was linearly proportional to the concentration of lysozyme up to $0.03 \mathrm{mg} / \mathrm{ml}$ in the $0.5 \mathrm{ml}$ of lysozyme solution added to the $2.5 \mathrm{ml}$ of substrate. The comparison between different samples of lysozyme in any given experiment was always made by using the same $M$. lysodeikticus suspension.

There was the possibility that the activity of emulsions at pH2.0 might change with time after dilution with the pH6.24 buffer. However, it was found that this activity remained constant after dilution over a period of $1 \mathrm{~h}$.

The enzymic activity of an emulsion stabilized with lysozyme is the sum of the activities of the lysozyme in solution in the aqueous phase and that adsorbed on the hydrocarbon surface. By measuring first the activity of the emulsion, and secondly that of the separated aqueous phase, the activity of lysozyme adsorbed on the hydrocarbon surface can be found by difference. In this way it was found that lysozyme in the aqueous phase, which had previously been in contact with hydrocarbon, had an activity of $90 \pm 10 \%$ of its original activity. Lysozyme on the hydrocarbon surface had an activity of only $10 \%$ of the original. Lysozyme was also removed from the interface, either by reequilibrating the hydrocarbon phase in pH 2.0 buffer or with a buffer containing a long-chain alcohol, and was found to have retained $75 \pm 10 \%$ of its original activity.

Ribonuclease. Cytidine 2':3'-cyclic monophosphate solutions of approx. $0.2 \mathrm{mg} / \mathrm{ml}$ of $\mathrm{pH} 7.0$ buffer were used as the substrate for comparing the activities of different ribonuclease solutions. As with lysozyme the initial slope of the extinction change-time curve was linearly proportional to the concentration of enzyme.

The activity of ribonuclease on the interface was found to be $15 \pm 10 \%$ of its original activity. When the hydrocarbon phase was removed by ultracentrifugation the protein solution that remained had $100 \pm 10 \%$ of its original activity. The ribonuclease that had been removed from the interface had $100 \pm 10 \%$ of its original activity.

\section{DISCUSSION}

Previous workers in the field had pre-formed their emulsions before adding the proteins, either by mechanical stirring (Fraser et al. 1955; Fraser \& Schulman, 1956; Cockbain, 1956) or by ultrasonic vibration (Ghosh \& Bull, 1962, 1963). In the present work the emulsions of decane were allowed to form spontaneously in the presence of proteins with only gentle agitation. (Under these conditions the amount of decane emulsified depends on the 
concentration of protein; if no protein is present no emulsion is formed.) Emulsification occurs when a layer of protein forms at the decane-water interface, thus lowering the surface free energy between the two liquid phases. The rate-limiting factor in the formation of emulsions appears to be the adsorption of the protein rather than the break-up of the hydrocarbon phase, since prior treatment with ultrasonic vibration has no effect.

The amount of protein lost from solution when an emulsion is formed increases with the amount of decane added until a limit is reached (Fig. 1). It is likely that, until this limit is reached, all the decane present is emulsified, after which free decane will also be present. The area of the hydrocarbon/ water interface could not, unfortunately, be measured as the distribution of particle size proved to be too great for satisfactory measurements with a Coulter counter. Other methods, such as displacement of protein with detergent (Cockbain, 1956) are liable, in themselves, to alter the particle size (Rehfeld, 1967). Nevertheless it may reasonably be assumed that the area of emulsion formed increases with the amount of decane added until the point is reached where there is no further loss of protein from the aqueous phase. It therefore appears that a definite concentration of protein is needed in the aqueous phase to maintain the layer of protein on a given area of interface.

Three of the four proteins studied, namely bovine serum albumin, lysozyme and insulin, were found to bind decane in aqueous solution under the conditions used to form emulsions. The amount of decane bound, $\bar{\nu}$, was related to the volume of decane added, although this was always far in excess of the amount needed to saturate the solution. Thus Figs. 2, 3 and 4 show the increase in $\bar{\nu}$ with decreasing protein concentration with a fixed volume of decane. Fig. 5 shows the increase in $\vec{v}$ as the volume of decane is increased with a fixed concentration of protein.

It therefore appears that conditions giving rise to the maximum loss of protein from the aqueous phase of an emulsion, e.g. the maximum area of interface, also give rise to maximum binding of decane by the protein remaining in the aqueous phase, suggesting that the two phenomena are intimately related. This relationship, i.e. between the curves shown in Figs. 1, 2, 3, 4 and 5, is illustrated diagrammatically in Fig. 6. Curve I shows the variation of decane binding with various protein concentrations and a fixed volume of decane. The situations represented by points $a, b$ and $c$ are shown in curves II, III and IV in terms of variation of $\bar{\nu}$ and the loss of protein from solution with different volumes of decane. At $a$ the volume of decane present is small and $\bar{\nu}$ and the losses of protein from solution are small, whereas at $c$ the
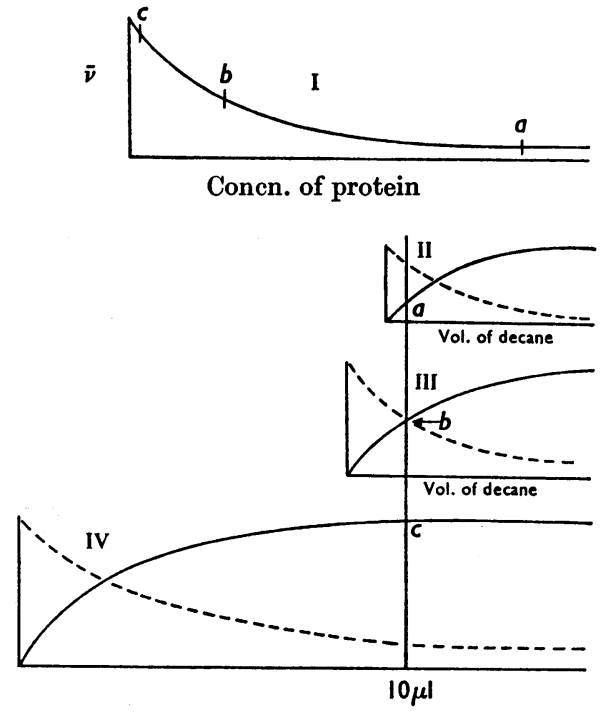

Vol. of decane

Fig. 6. Schematic representation of the number of mol of decane bound $/ \mathrm{mol}$ of protein $(\bar{\nu})$ at different protein concentrations. Curve I shows $\bar{\nu}$ plotted against protein concentration. Curves II, III and IV show the equivalent of Fig. 5 for points $a, b$ and $c$ on curve $I$, and they show the variation of $\bar{v}(-)$ and the equilibrium protein concentration (---) plotted against the volume of decane added. The vertical line shows in each case the point corresponding to $10 \mu \mathrm{l}$ of decane.

volume of decane is large and $\bar{\nu}$ and the losses of protein from solution are correspondingly large.

It has been shown that both the adsorption of protein on the hydrocarbon/water interface and the binding of decane by proteins are reversible. It is therefore reasonable to postulate that the proteinhydrocarbon-water system is in a state of dynamic equilibrium. The most probable mechanism is that protein molecules are adsorbed on the hydrocarbon surface, causing emulsification; at the same time protein molecules leave the surface, retaining, in some cases, some bound decane. This bound decane is subsequently lost and returns to the hydrocarbon phase. The observed value of $\bar{\nu}$ must represent a mean between, at one extreme, the value for protein leaving the interface with a maximum amount of bound decane and, at the other extreme, the value for protein that has been out of contact with the interface for sufficiently long to have lost its decane. This situation is different from that described by Wishnia (1962), who used more soluble hydrocarbons, e.g. butane and propane, so that the whole system was contained in a single phase. The system used in the present work is considerably more complex and, until satisfactory measurements 
of the area of the decane/water interface are available, can only be described qualitatively.

The contribution of decane in free solution has been ignored. Since the solubility of decane in the buffer solutions (approx. 1.0 nM) is several orders lower than the lowest concentration of protein used, it is likely to be small. It is nevertheless of note that when Ray et al. (1966) equilibrated bovine serum albumin with saturated solutions of dodecan1-ol they obtained a similar relationship between $\bar{\nu}$ and protein concentration, although the values of $\bar{\nu}$ were much lower than those observed with decane. Ray et al. (1966) attribute the concentrationdependence of the binding of dodecanol to the fact that the alcohol can adhere to more than one molecule of protein and so lead to partial dimerization of the albumin. However, there is no evidence to show that dimerization occurs under these conditions (Phelps \& Putnam, 1960).

The most likely explanation for the low enzymic activity of lysozyme and ribonuclease when adsorbed on the hydrocarbon/water interface is that the active sites are oriented towards the hydrocarbon phase. This view is consistent with the complete recovery of activity that was obtained on desorption. Another possibility is that the $\mathrm{pH}$ of the interface may differ from that in the solution. This is shown to be unlikely in this case in that the dimerization of lysozyme, which occurs in solution at pH 5.5-6.0 (Sophianopoulos \& van Holde, 1964), has been found to occur on the interface at the same pH (Cecil \& Louis, 1970).

Ghosh \& Bull (1962) studied the adsorption of chymotrypsin on pre-formed emulsions of $n$-octadecane. Their findings differed from those in the present work in several respects. The activity of the enzyme was decreased at the interface and also, to a smaller extent, in solution. Moreover, adsorption on to the hydrocarbon phase appeared to be irreversible.

The fact that the two intracellular proteins were denatured in the presence of decane is not surprising, since intracellular proteins normally contain no disulphide bonds, which give increased structural stability to extracellular proteins (Cecil, 1963). Fraser et al. (1955) found that catalase, an intracellular protein, is irreversibly inactivated in pure nonane emulsions and that $90 \%$ of the catalase originally in solution was adsorbed irreversibly on the emulsion, indicating that it must unfold on the surface.

Elkes et al. (1945) have shown that human haemoglobin, removed from oil-in-water emulsions, was different in many of its properties from native haemoglobin, and solubility and colour tests indicated that the haemoglobin molecule had been broken down with the separation of parahaematin.

C.F.L. is indebted to the Science Research Council for support during the period of this work.

\section{REFERENCES}

Blades, A. N. \& Flavell, H. C. G. (1963). J. clin. Path. 16, 158.

Cecil, R. (1963). In The Proteins, 2nd ed., p. 379. Ed. by Neurath, H. New York: Academic Press Inc.

Cecil, R. \& Loening, U. E. (1960). Biochem. J. 76, 146. Cecil, R. \& Louis, C. F. (1970). Biochem. J. 117, 147.

Cecil, R. \& Weitzman, P. D. J. (1964). Biochem.J. 93, 1. Cockbain, E. G. (1956). J. Colloid Sci. 11, 575.

Crook, E. M., Mathias, A. P. \& Rabin, B. R. (1960). Biochem. J. 74, 234.

Elkes, J. J., Frazer, A. C., Schulman, J. H. \& Stewart, H. C. (1945). Proc. R. Soc. A, 184, 102.

Foster, J. F. \& Sterman, M. D. (1956). J. Am. chem. Soc. 78, 3656.

Fraser, M. J., Kaplan, J. G. \& Schulman, J. H. (1955). Discuss. Faraday Soc. 20, 44.

Fraser, M. J. \& Schulman, J. H. (1956). J. Colloid Sci. 11, 451 .

Ghosh, S. \& Bull, H. B. (1962). Archs Biochem. Biophys. 99, 121.

Ghosh, S. \& Bull, H. B. (1963). Biochim. biophys. Acta, 66, 150.

Lowry, O. H., Rosebrough, N. J., Farr, A. L. \& Randall, R. J. (1951). J. biol. Chem. 193, 265.

Mohammadzadeh-K., A., Feeney, R. E., Samuels, R. B. \& Smith, L. M. (1967). Biochim. biophys. Acta, 147, 583.

Nyman, P. O. \& Lindskog, S. (1964). Biochim. biophys. Acta, 85, 141.

Olson, J. A. \& Anfinsen, C. B. (1952). J. biol. Chem. 197, 67.

Phelps, R. A. \& Putnam, F. W. (1960). In The Plasma Proteins, lst ed., p. 143. Ed. by Putnam, F. W. New York: Academic Press Inc.

Ray, A., Reynolds, J. A., Polet, H. \& Steinhardt, J. (1966). Biochemistry, Easton, 5, 2606.

Rehfeld, S. J. (1967). J. Colloid Sci. 24, 358.

Reynolds, J. A., Herbert, S. \& Steinhardt, J. (1967). Biochemistry, Easton, 6, 937.

Sela, M., Anfinsen, C. B. \& Harrington, W. F. (1957). Biochim. biophys. Acta, 26, 502.

Shugar, D. (1952). Biochim. biophys. Acta, 8, 302.

Sophianopoulos, A. J. \& van Holde, K. E. (1964). J. biol. Chem. 239, 2516.

Sophianopoulos, A. J., Rhodes, C. K., Holcomb, D. N. \& van Holde, K. E. (1962). J. biol. Chem. 237, 1107.

Wishnia, A. (1962). Proc. natn. Acad. Sci. U.S.A. 48, 2200.

Wishnia, A. \& Pinder, T. (1964). Biochemistry, Easton, 3, 1377. 